DOI: https://doi.org/10.46630/phm.12.2020.28

Мирјана Д. Бојанић Ћирковић ${ }^{1}$

Оригинални научни рад

Универзитет у Нишу

УДК 82.0

Филозофски факултет

028.02

Департман за српску и компаративну књижевност

Примљен: 23. 2. 2020.

\title{
КОНЦЕПТ ИМПЛИЦИТНОГ ЧИТАОЦА ВОЛФГАНГА ИЗЕРА
}

У раду се систематизацију и критички разматрају теоријско-методолошка истраживања имплицитног читаоци, концепта који је афирмисао Волфганг Изер (Wolfgang Iser), значајан теоретичар читања у савременој науци о књижевности. Концепт имплицитног читаоца се сагледава у релацији са сродним методолошким концептима наратолога и теоретичара читања (наративном и ауторском публиком Џејмса Фелана), при чему се, у рекурзивном односу, осветљавају и нове перспективе концепта који је предмет разматрања овог рада. Значајан део рада посвећен је активностима, могућностима и ограничењима емпиријског читаоца у улози имплицитног читаоца. У закључку рада указујемо на допринос концепта имплицитног читаоца савременим теоријама читања и на разлоге његове актуелности у науци о књижевности.

Кључне речи: Волгфанг Изер, имплицитни читалац, празно место, значење, теорије читања

\section{1. Теоријско-методолошки оквир истраживања Волфганга Изера}

Волфганг Изер је својим укупним књижевнотеоријским радом² значајно допринео савременим теоријама читања. ${ }^{3}$ Након Романа Ингардена,

\footnotetext{
${ }^{1}$ mirjana.bojanic.cirkovic@filfak.ni.ac.rs

2 Прву фазу Изерових теоријско-методолошких истраживања карактерише корекција формалистичког иманентизма у смеру редефинисања дела као затворене и довршене целине у отворен, процесуалан и динамичан текст, а потом и дијалошка релација између поступака очуђавања (остранение) и празних места (gaps) у структури књижевног текста на основу њихових позитивних ефеката у процесу активног читања. У овој фази Изер кодификује концепт енкодираног читаоца. Другу фазу Изерових истраживања карактерише спој феноменолошке и рецепционистичке оријентације, а у њој се поменути аутор фокусира на процес читања, читаочеву интеракцију са текстом, његове селекцијске одлуке, улогу лутајућег мотришта (Wandering Viewpoint), конкретизацију и, најзад, на концепт имплицитног читаоца. Трећу фазу истраживања поменутог теоретичара (The Range of Interpretation) карактерише приближавање антрополошким и посткласичним, когнитивно усмереним наратолошким студијама.
}

${ }^{3} \mathrm{O}$ савременим теоријама читања писали смо у истоименом раду, објављеном у часопису 
Волфганг Изер је први теоретичар читања који је теоријско-методолошки прецизно осветлео усмеривачку и контролну функцију празних места (gaps) у процесу читања и њихову улогу у интеракцији читаоца и текста, при чему је нарочито указао на потенцијал празних места за читаочеву сатворачку улогу у конфигурацији значења. Потом, наведени теоретичар је значајан за афирмацију имплицитног читаоца као важног интерпретативног метода, насталог у релацији према Бутовом (1961) имплицитном аутору, а, унутар наративног комуникацијског канала, подређеног стварном аутору и емпиријском читаоцу. У теорији читања Волфганга Изера сусрело се више различитих теоријских поставки - од феноменолошких, наратолошких, рецепционистичких, до оних афирмисаних у крилу критике читалачког одговора, што је у дијахронијским прегледима често резултовало сврставањем Изерових истраживања у дивергентне теоријске оквире. ${ }^{4}$ Међутим, управо је методолошка интерференција (превазилажење формалистичке ригидности, али задржавање значаја структуре текста и његове подстицајне улоге у процесу читања) оно што Изерова истраживања чини актуелним.

Кодификовање концепта имплицитног читаоца сматрамо највећим Изеровим доприносом теоријама читања, а универзалност и широк домен његове апликативности, бројни концепти ${ }^{5}$ настали у настојању да се опише онај сегмент имплицитног читаоца који се односи на начине попуњавања празних места, нови проблеми изнедрени из поменутог интерпретативног метода као што је његова мултипликација унутар једног текста, права су потврда виталности овог Изеровог концепта.

\section{2. Концепт имплицитног читаоца}

Полазећи од замерки концептима читалаца усмерених ка резултатима (ефектима, реакцијама) ${ }^{6}$ емпиријских читалаца, Изер своју теорију

Philologia Mediana бр. 10, 2018. (в. Бојанић Ћирковић 2018: 89-102).

${ }^{4}$ Изерова имплементација дивергентних методолошких оријентација наишла је и на критике. Стенли Фиш у тексту Why No One's Afraid of Wolfgang Iser (1981) Изеров методолошки синкретизам назива свесним подилажењем опречним теоријским поставкама са циљем да се и формалистима и деконструктивистима омогући да унутар једне теорије читања пронађу „баш оно што им одговара” (FIŠ 1981: 1-2). Фишове замерке Изеровој теорији највише се односе на пренаглашавање приоритетности и стабилности текста, те на његов усмеривачки и контролни карактер (уп. са потпуно супротним Фишовим тезама о читању као стварању текста устудији Interpreting the Variorum).

${ }^{5}$ Ово се односи на одређене асимилације или модификације овог концепта унутар посткласичних наратолошких оријентација. О њима пишемо у завршном делу рада.

6 Унутар критике читалачког одговора, превасходно психолошке и психоаналитичке 
читања заснива на потенцијалу у тексту који изазива „ре-креативну дијалектику у читаоцу" (IZER 1978: 30). Тако је у теорији читања овог аутора узета у обзир читаочева улога која је, с једне стране, уписана у текст, а која се реализује и на историјском, и на појединачном плану јер опште околности и читаочева знања неминовно утичу на сам процес читања.

При одређењу фигуре имплицитног читаоца7, Изер, доследно својим теоријским поставкама у вези са процесом читања, полази од „места” са којег текст читаоца позива на интеракцију са њим. На Ингарденовом трагу, овај текстуални минус-елемент (односно минус-релацију, минус-аспект) Изер назива празним местом. У овом сегменту Изерове теорије који се односи на функције ненаписаног дела текста налазимо не само разлику у односу на Ингарденову концепцију читања, већ и полемику са њом. За разлику од теорије Романа Ингардена где места неодређености означавају само оно што књижевним уметничким делима $a$ priori недостаје, а то је свестрана дефинисаност, и који сматра да места неодређености треба што више отклонити већ приликом компоновања књижевног уметничког дела, Изер празнине у тексту сматра пожељним јер стимулишу читаочево учешће; оне га увлаче у радњу, наводе да конкретизује оно што је у тексту сугерисано и позивају га на „ukrcavanje u tekst" (IZER 2002: 144) и интеракцију са њим, али уз извесна ограничења која поставља написани део текста, што је опште место не само Ингарденове и Изерове, већ и потоњих теорија читања.

Иако Волфганг Изер у првим радовима из области теорије читања истиче да су празнине у тексту оно што покреће (и, истовремено, контролише) читаочеву активност, опсежније их одређује тек у Чину читања, насталом током рецепционистичке фазе његових теоријских разматрања процеса читања:

„Praznine upućuju na to da različiti segmenti i primerci teksta treba da budu povezani, iako sam tekst ne nalaže tako. One su nevidljivi spojevi teksta, koji jednovremeno razdeljuje sheme i tekstualne perspektive i podstiču stvaranje ideja kod čitalaca. Naravno, kada su sheme i perspektive opet povezane, praznine 'nestaju'." (IZER 1989: 55)

оријентације, постоји низ студија усмерених ка истраживању реалних читалаца и њихових субјективних доживљаја конкретног књижевног текста. У овом контексту, каракеристичан је концепт трансактивног читаоца који афирмише Норман Холанд.

${ }^{7}$ Годину дана након Изеровог увођења имплицитног читаоца у корпус теорија читања, Џералд Принс (1973) у нешто измењеном значењу уводи термин „Lecteur Virtuel” (текстоцентрични концепт) којег постулира имплицитни аутор, а Волф Шмид, више усмерен ка пољским теоретичарима рецепције, уводи концепт „Abstrakter Leser” који потом раздваја на две инстанце: „Presumed Addressee” и „Ideal Recipient”, при чему је овај други члан ближи Изеровом значењу. 
Волфганг Изер имплицитног читаоца у истоименој књизи (Implied Reader $)^{8}$ одређује као „ulogu čitatelja upisanu u roman”, односно као стратегију текста и „uvjet mogućeg djelovanja” (IZER 1989: 64). Међутим, прагматички оријентисан Волфганг Изер значење књижевног уметничког дела сагледава као нешто што се констутиише тек у историјски конкретном односу између текста и читаоца: „A kad čitaočeva imaginacija oživi te 'naznake',one, sa svoje strane, počinju djelovati na napisani dio teksta. Tako otpočinje cijeli jedan dinamički proces." (IZER 2002: 142-143) Овој читаочевој улози у изградњи виртуелне димензије текста посвећено је читаво поглавље Изеровог Имплицитног читаой , а поменута „улога” - суделовање, уплетеност, за који год од ових синонима се определили, могућа је захваљујући иманентном својству књижевноуметничког текста - празнинама које читалац испуњава својим закључцима, пратећи текстуалне импликације. Грађу коју је Волфганг Изер истраживао и на основу које је описао концепт имплицитног читаоца чине дела Хенрија Филдинга, Џејмса Џојса, Вилијема Текерија, Тобијаса Смолета, Самјуела Бекета, Вилијама Фокнера, Валтера Скота, Џона Бањана. ${ }^{9}$

Позиција са које Изер (1989: 53) дефинише концепт имплицитног читаоца у првој фази својих истраживања („Апелативна структура текста", Имплицитни читалаи) је феноменолошка, ингарденовска јер „čitatelj izvodi smislenu konfiguraciju romana” уз „neophodne kontrole koje će spriječiti da se dopušteni prostor aktuelizacije po želji proširuje" (IZER 1989: 53). ${ }^{10}$ Међу текстуалним „контролама” које усмеравају читање, Изер као најефектнија експлицитна средства издваја коментаре. Поред приповедачевих коментара (у првом реду апелативних), Изер (1989: 53) средствима експлицитног управљања сматра и разне видове паратекста као што су аутопоетичке белешке, есеји о теорији жанра и сл.

Поред експлицитног управљања, концепт имплицитног читаоца као стратегија текста и читања обухвата и имплицитно управљање реакцијама емпиријског читаоца и његовом конфигурацијом значења романа. Након анализе читаочеве „улоге уписане у текст” Филдингових романа ${ }^{11}$,

\footnotetext{
${ }^{8}$ Прво издање Изерове монографије Имплицитни читалаи било је на немачком језику (Der implizite Leser. Kommunikationsformen des Romans von Bunyan bis Beckett, 1972). Цитате из ове Изерове књиге у раду наводимо према енглеском издању, из исте године.

${ }^{9}$ Навешћемо проблеме које је истражио Волфганг Изер у опусу поменутих писаца: наративна прогресија Пилгрима и њен ефекат у процесу читања; читаочева улога у Џозефу Ендрjусу и Тому Џонсу; читалац као саставни елемент реалистичког романа; генерисање значења и естетички одговор у Смолетовим пикарским романима; перцепција, време и акција као модуси субјективности у Буци и бесу; комуникацијске схеме у Уликсу и др.

${ }^{10}$ Уп. са INGARDEN 1971: 54.

11 Приликом описивања имплицитног читаоца Филдингових романа Изер анализира целокупни сигнални комплекс који било експлицитно, било имплицитно управља
} 
Изер систематизује њихова средства имплицитног управљања процесом читања, те издваја:

a) скицирани контрастни принцип као „primarno određenu strategiju [Fildingovih] romana" (IZER 1989a: 56) и садржитеља важних напомена за улогу намењену емпиријском читаоцу. Контраст као стратегија Филдингових романа постоји на више структурних нивоа, а, по Изеровом запажању, најопсежнији је на нивоу фабуле. Према Изеровим запажањима, Филдингов имплицитни аутор кључ романескне радње држи у контрастној релацији. Дакле, једна од стратегија Филдингових романа је интендирање читања путем скицираног контрастног принципа, са циљем да емпиријски читалац премости „,razliku kontrastne relacije”, те да се „uključi u tvorbu predodžaba nužnih za shvaćanje intendiranog fenomena" (IZER 1989: 55). Преузимање улоге читаоца уписаног у Филдингов роман, дакле, резултује ,рефлектованим читањем” и у том процесу позитивно утиче на на изоштравање запажања емпиријског читаоца. Преструктурирана контрастна опозиција текста уједно је и средство контроле ${ }^{12}$ у процесу читалачког конструисања виртуелне димензије текста, односно, естетског пола романа Хенрија Филдинга.

б) празна места текста као „misaone pauze ponuđene čitatelju” (IZER 1989a: 59). ${ }^{13}$ Проблем празних места Изер најпре разматра у „Апелативној структури текста", објављеној две године пре књиге Имплицитни читалац. Емпиријски читалац испуњава празна места текстовним импликацијама или наслућивањима. ${ }^{14}$ Иако Изер то не експлицира, јасно се уочава да су принципи које издваја у оквиру анализе улоге читаоца уписаног у текст градирани према степену њихове динамике у процесу читања. Попуњавање празних места импликацијама из текста додатно динамизује процес читања као „стављања у интеракцију” опозиције уписане у сам књижевноуметнички текст. У процесу читања, „мисаоне паузе” стимулишу читаоца да се удуби у догађање у наративу, како би могао да конструише његов смисао.

реакцијама емпиријског читаоца и његовом конфигурацијом значења.

${ }_{12}$ Изер стратегију опозиције квалификује и као „značajnu strategiju manipulacije čitatelja” (IZER 1989: 56).

13 Једна од таквих „мисаоних пауза” у Филдинговим романима настаје услед ауторовог сажимања приче на значајне догађаје (IZER 1989: 59), док је већи део празних места последица контраста као композиционог принципа Филдингових романа.

${ }^{14}$ У Чину читања Изер (1978: 169) још једном истиче контролну функцију празних места и негација у процесу интеракције између текста и читаоца, односно, током читања: празна места остављају отвореним конекције између перспектива у тексту, те подстичу и усмеравају читаочеву активност (операције) у тексту, док негације призивају познате и одређене елементе текста како би их искључиле, односно, оне усмеравају читаоца да усвоји одређену позицију у односу на текст. О функцији негација у процесу читања из угла когнитивне наратологије писала је MILOSAVLJEVIĆ MILIĆ 2015: 57-82. 
в) фингирани дијалог са читаочем као средишње начело структурирања Филдиноговог романа (подржано и паратекстуалним елементима, те есејима поменутог аутора), у оквиру којег је фреквентна улога адвоката коју поменути аутор приписује својим читаоцима. ${ }^{15}$ Примарну функцију ове, како је сам назива, „правне метафорике” Филдингових романа, Изер налази у „navođenju čitaoca na odmjerene sudove” (IZER 1989: 64).

г) уметнуту причу ${ }^{16}$ као „појачало” које служи да се осигура читаочево „,razumijevanje u smislu autorove namjere” (IZER 1989a: 56). Међутим, Изер (1989: 56) наведену стратегију из угла њене ефикасности оцењује као естетски мање вредну, a „razlog je u prevelikoj jasnoći čitatelju nametnutog zaključka" (IZER 1989: 58), односно, у одсуству поверења према извантекстовном читаоцу. ${ }^{17}$

Изеров закључак о уграђеним стратегијама читања Филдингових романа више иде у прилог средствима контроле читалачке реакције, него афирмацији читалачке слободе; међутим, његов општи став по питању евентуалне контроле читалачке реакције потире априорну ефикасност чак и најдиректније стратегије, као што су апелативни коментари и уметнута прича. Иако је Филдинг као романописац велику пажњу посветио избору стратегија које ће у што већој мери осигурати читаоцу његових романа „razumevanje u smislu autorove intencije”, оне су пре „okvir sa selektivnim odlukama” (IZER 1989: 64) него скуп средстава за детерминисање реакција читалаца, ако ни због чега другог, онда због хетерогености саме читалачке публике међу којом ће се свакако наћи и онај скептични читалац који ће у минималној мери преузети улогу имплицитног читаоца Филдинговог романа, односно следити улогу читаоца уписану у роман. Јован Попов (1993: 62) пишући о Изеровој теорији читања закључује да овај аутор не пренебрегава оно што је у самој бити читања - неисцрпивост: „Ако би читалац послушно и до краја обављао оно што текст од њега захтева, не би ли у том случају изгубио своју функцију?”

Поред доприноса који се огледа у оцртавању концепта имплицитног читаоца и примеру његове апликативности у контексту Филдингових романа, интересантно је запажање Волфганга Изера (1989: 66) у вези са оцртавањем Филдингове ауторске публике (иако терминолошки није

\footnotetext{
${ }^{15}$ Примера ради, у једном од есеја Филдинг пише о публици коју прижељкује: „uvjeren sam da će većina mojih čitatelja biti bolji advokati jadnom Jonesu” (IZER 1989: 63).

16 Функцију уметнуте приче Изер експлицира и на следећи начин: „Umetnute priče izvrću intenciju glavne radnje u njezinu suprotnost, da bi na taj način čitateljev pogled bez nesporazuma usmjerile na središnju temu." (IZER 1989: 58)

${ }^{17}$ На односу узајамног поверења аутора и ауторске публике изграђена је теорија наративне етике Џејмса Фелана. У оквиру ове теорије, Фелан је фокусиран на анализу наративних техника (у првом реду, непоуздане нарације) које указују веће поверење читаоцу.
} 
уобличено кроз наведену синтагму): ауторска публика поменутог романописца (односно, његов жељени читалац од крви и меса) није класно диференцирана, али се рачуна на низ њених компетенција, међу којима су способност изоштреног запажања (оштроумље) и умеће надилажења социјалне опозиције у роману, те способност за спознају саме људске природе.

У другој фази својих теоријских разматрања (у Чину читања и у радовима насталим након ове монографије) Изер ће инсистирати на томе да су места неодређености у потпуности променила однос између текста и читаоца. Тако интеракција између текста и читаоца сада не само да подразумева обострани утицај, већ у значајнијој мери бива усмеравана читаочевим диспозицијама. Како су закони који регулишу међуделовање текста и читаоца расути у тексту, читалац их „мора најпре сабрати или, у већини случајева, поново саставити да би се могао успоставити било какав референцијални оквир" (IZER 1989: 53).

У монографији Чин читања, која представља даљу разраду поставки о читању као интеракцији између текста и читаоца, односно као динамичком процесу производње значења и естетског пола дела, Изер подробније описује елементарне активности (операције) на које текст подстиче читаоца. Тежиште ове Изерове студије је на ефектима, одговорима и својствима - али не ни текста, ни читаоца, већ њихове интеракције. Текст се и даље посматра као скуп инструкција, те Изер опет полази са овог поља јер у њему налази потенцијал значења текста, чије је описивање један од циљева поменуте Изерове студије. Чин читања обогаћује Изеров теоријски корпус ${ }^{18}$ новим појмовима и концептима као што су „лутајуће мотриште” (wondering viewpoint), mема као сегмент перспективе на којем се тачка гледишта зауставља у процесу читања, односно „важна информација” (IZER 1978: 96), те хоризонт као позадински план на који се пројектује сваки наредни сегмент наратива. Концепт имплицитног читаоца Чином читања продубљен је у смеру интеракције између текста и читаоца те је, како се може закључити из поменуте Изерове књиге, модификација овог концепта у дијахронијском прегледу Изерових теорија замашно искорачила ка чину осмишљљваюа у процесу читања. Поменути концепт је проширен „лутајућим мотриштем” као модусом читаочеве присутности у тексту. Текст, раслојен на „unutarnje horizonte sjećanja i očekivanja" (IZER 1992: 158), сам по себи, без активног читања, не може да стави у интеракцију перспективе текста, те да доведе до конфигурације његовог значења. Процес интеракције текста и читаоца јесте скициран, али без чина активног читања остаје нефункцио-

18 Кључне речи Изерове теорије читања до Чина читања јесу празнине (gaps/blanks/ vacancies), негација, кохеренциија и осмищљавање. 
налан. Основ Изеровог схватања текста јесте присуство читаоца у тексту, при чему се мисли на ингарденовски активно читање где лутајуће мотриште разлаже текст на његове интеграцијске структуре, синтетише их, групише, сажима и непрестано модификује услед новоосветљених перспектива текста.

\section{3. Емпиријски читалац у улози имплицитног читаоца: активности, могућности и ограничења у конфигурисању значења књижевног дела}

Сам ток процеса читања, из угла активности емпиријског читаоца, почиње селекцијским одлукама које су назначене у тексту: „lepeza mogućnosti značenja [...] je strukturno unaprijed zadana svakoj subjektivno uvjetovanoj realizaciji." (IZER 1992: 163-164) Дакле, у самом тексту постоје модалитети који врше директан утицај на читаочеве селекцијске одлуке и процес конфигурације значења. Иако је, по Изеру, конфигурација значења и реализација естетског пола дела условљена и одвија се само у домену могућности назначених у тексту, она је подједнако условљена читаоцем те, позивајући се на Сартра, Изер (1992: 164) такође заузима став да „,̌itatelj ipak mora napraviti baš sve iako je sve već napravljeno.” Када је у питању емпиријски читалац, Изер осветљава „удео илузије” у процесу читања, односно на степену читаочеве уплетености у текст. Поменуте одлике чина читања Изер појашњава на следећи начин: најпре, предуслов читања као интеракције између текста и читаоца подразумева остављање реалности и субјективног искуства за собом, те предано и помно, односно, како ће посткласичне теорије читања то артикулисати, уроњено (immersed) читање:

„Putem ustrojavanja mi participiramo u tekstu, a to znači da smo obuzeti onime što proizvodimo. Stoga često imamo dojam da za vrijeme čitanja živimo neki drugi život. [...] To sudelovanje u tekstu je iluzija utoliko što zbog ovakve obuzetosti ostavljamo za sobom ono što jesmo.” (IZER 1992: 168).

Иако је, како сматра Волфганг Изер, у природи процеса читања „остављање за собом онога што јесмо”, овај аутор не занемарује „interakciju između sadašnjosti teksta i našeg iskustva potisnutog u prošlost.” (IZER 1992: 174) Наше субјективно искуство има великог удела у селекцијским одлукама током чина читања јер се селекцијске одлуке најпре врше „prema onom delu stranog iskustva koji se još čini poznatim." (IZER 1992: 167) У одељку „Карактер догађања као корелат свести текста” Чина читања, Изер експлицира овакав вид интеракције читаочевог искуства са самим текстом у поменутом процесу: 
„Kad u čitanju nekog fikcionalnog teksta nastane interakcija između njegove nazočnosti u meni i mojeg iskustva nastalog u prošlosti, koja se manifestira u izmeničnom djelovanju preslojavanja i oblikotvorenja, onda to znači da shvaćanje takvog teksta nije pasivni postupak usvajanja, već produktivni odgovor na doživljenu diferenciju." (IZER 1992: 176)

Можемо закључити да читаочево стечено искуство, поред тога што врши директан утицај на читаочеве селекцијске одлуке, током интеракције са текстом поново оживљава, преслојава се, преобликује, односно, рекреира. $^{19}$

Изерова теорија читања значење књижевног текста сагледава се као Gestalt, односно као конфигурацију коју, иако насталу сажимањем, односно читаочевом селекцијском одлуком између више могућности, те укидањем напетости услед неодређеног или неизреченог ${ }^{20}$, непрестано подривају латентне тензије јер се ни читаочев „udeo u Gestaltu”, како би рекао Изер (1992: 160), ни само значење текста не исцрпљују поменутим активностима. ${ }^{21}$

С обзиром на то да се у Чину читања налазе и сегменти посвећени улози читаочевог индивидуалног искуства у процесу интеракције са текстом, Изер своје ставове о контроли интеракције ипак значајно модификује у односу на оне изнете у претходним текстовима. На питање: „Ко/ шта врши контролу интеракције између текста и читаоца?”, Волфганг Изер (1992: 176) даје јасан одговор: „Nijedan vladajući kod ne može izvršiti tu kontrolu, kao ni iskustva sedimentirana u čitatelju; jer, estetsko iskustvo transcendira njih oboje." Овим је у великој мери текстоцентрични концепт имплицитног читаоца надграђен оним што је у самој природи процеса читања - непрестаним читаочевим лебдењем између обузетости текстом

\footnotetext{
${ }^{19}$ Наведена промена је опште место посткласичних наратолошких концепција усмерених ка когницији и процесу читања, те се она, примера ради, код Пола Рикера означава као мимезис III, односно као реструктурирање (рефигурисање) читаочеве перцепције стварности путем наратива, а код Вернера Волфа (WERNER WOLF 2006) одређује као модификација когнитивног оквира. Проширење когнитивних оквира путем ангажовања са искуством отеловљеним путем наратива овде обухвата физичке, друштвене и културне параметре.

${ }^{20}$ Поменуте активности које је могуће реализовати тек „присуством у тексту”, односно модусом лутајућег мотришта, само су један корак кроз текст, односно један моменат у процесу читања. Свако тренутно формирање значења Изер назива периептуалном поемом. С обзиром на то да се односи на повезивање и конкретизацију импликованих аспеката у тексту, те на нешто што се током читања непрестано модификује, перцептуална поема је увек корак ка формирању значења књижевноуметничког текста.

${ }^{21}$ „Selekcijske odluke pri čitanju istovremeno proizvode izvesni višak mogućnosti.” (IZER 1992: 167) Управо тај испрва занемарени вишак могућности, током читања може постати значајан за конфигурацију значења књижевноуметничког текста јер може изменити смер читаочеве селекцијске одлуке и, самим тим, модификовати претходно конфигурисано значење.
} 
и његовог проматрања, „покретањем” текста и уплитањем у његово догађање које само емпиријски читаоци могу омогућити. Бити у интеракцији са текстом, по Изеру, значи бити присутан у тексту.

Примарна функција имплицитног читаоца јесте пружање смерница за актуализацију значења књижевног текста. Али чињеница да актуелизација текста може бити извршена на различите начине у складу са историјским или индивидуалним околностима, а за које има импликација у тексту, уједно је и аргумент да је структура текста та која омогућава различите начине испуњавања. Процес актуелизације увек је селективан и било која актуализација може се разматрати у контексту других, потенцијално присутних у текстуалној структури. ${ }^{22}$

Када је у питању конфигурација смисла књижевног текста, што je једна од примарних функција узимања улоге имплицитног читаоца, можемо закључити да је Изер одбацио класична тумачења значења ${ }^{23}$ и створио простор за успостављање нове, модерне концепције те теме. По Изеру, значење књижевног текста се конфигурише у читаочевој свести на различите начине у зависности од његовог дејства на читаоца, те у односу на читаочеве индивидуалне особине, социјално окружење, друштвеноисторијске норме које је усвојио одређени читалац али које, с друге стране, предодређују потенцијалног читаоца одређеног књижевног текста. Значење књижевног текста, дакле, није само резултат откривања његових смисаоних потенцијала, већ делом улази у домен деловања текста у читаоцу јер, као што смо већ истакли говорећи о Изеровој теорији читања, откривене многоструке везе у тексту продукт су читаочеве активности.

\section{4. Допринос концепта имплицитног читаоца савременим теоријама читања}

Од 1972. године, када је афирмисан истоименом монографијом, концепт имплицитног читаоца значајно је модификован. Док је у првој фази Изерових истраживања имплицитни читалац био више текстоцентричан концепт, са прихватањем одређених рецепционистичких ставова и концепата критичара читалачког одговора у вези са процесом

\footnotetext{
${ }^{22}$ УП. „Each actualization therefore represents a selective realization of the implied reader, whose own structure provides a frame of reference within which individual responses to a text can be communicated to others. This is a vital function of the whole concept of the implied reader: it provides a link between all the historical and individual actualizations of the text and makes them accessible to analysis." (Uzer 1978: 37-38)

${ }^{23}$ Ово се односи на платоновско схватање књижевног дела као репрезентације одређеног значења које је унапред дато и садржано у њему, а које се открива (,извлачи” из дела) у поступку читања и интерпретације.
} 
читања, преко Чина читања, па надаље, домен Изеровог имплицитног читаоца проширује се на стање напрегнутости у којем се емпиријски читалац налази када прихвати улогу уписану у текст. Стога ћемо запажања о Изеровом концепту имплицитног читаоца систематизовати узимајући у обзир и онај аспект који се односи на уграђену стратегију читања, и онај који обухвата активности емпиријског читаоца.

Имплицитни читалац:

1. „присутан” је у сваком књижевноуметничком тексту;

2. није стварни читалац, већ је текстуални елемент, односно ентитет изводљив из текста; уцртана условност актуализације текста и улога коју у интеракцији са њим треба да преузме емпиријски читалац; 3. обухвата и сет менталних операција које су укључене у процес читања: селекције у избору и организовању информација, процесе отклањања празних места у тексту уз ограничења која поставља текст и др.;

4. не јамчи априорну потпуну реализацију; напротив, може да се реализује само селективно.

С друге стране, емпиријски читалац, као онај ко у процесу рецепције реализује уграђену стратегију текста и открива његов семантички потенцијал, према Волфгангу Изеру:

1. има улогу сабирања перспектива које су назначене у књижевном тексту и конфигурисања значења онога што је репрезентовано тим перспективама;

2. реализује најмање једну од могућих уцртаних актуализација књижевног текста;

3. констутуише значење текста вођен и условљен текстом. Текст не обухвата идеје стварног читаоца, али на њих делује.

Теоретичари који су писали о Изеровом имплицитном читаоцу указали су на вишеструке доприносе овог концепта. Џејн Томпкинс (1980: 16) Изеровог имплицитног читаоца дефинише као спону између произвођача и конзумента чија је функција да, дајући смернице кроз текст, управља рецепцијском равни. Наглашавајући текстовну позицију имплицитног читаоца, Томпкинс закључује да се Изер у првим теоријским текстовима није много удаљио од формализма. ${ }^{24}$ Јован Попов (1993: 62) Изеровог имплицитног читаоца одређује као „стање напрегутости у којем стварни читалац живи када прихвати своју улогу”, чиме је имплицитно скренуо пажњу на амбивалентан (али, у контексту његових „по-

\footnotetext{
${ }^{24}$ Овакав закључак Џејн Томпкинс произилази из опредељења поменутог аутора да у своју хрестоматију унесе само Изеров текст о феноменолошком приступу процесу читања, објављеном пре Чина читања.
} 
лова", комплементаран) карактер поменутог концепта: он је и стратегија текста и улога коју преузима стварни читалац, а кључни ефекти који се у процесу читања остварују узимањем наведене улоге (и који подстичу даље читање текста) јесу напрегнутост и неизвесност. Горана Раичевић (1997), аутор значајне студије о критици читалачког одговора, теорију Волфганга Изера сврстава у методолошки корпус који читање одређује као креацију. Снежана Милосављевић-Милић (2006: 32) Изеров највећи допринос савременим теоријама читања налази у издвајању апелативног коментара као једне од димензија неодређености у тексту. На овај аспект Изерове теорије често ће се позивати реторички теоретичари читања при разматрању ефеката непоузданог приповедања у процесу читања.

\section{5. Након Изера: празно место и начини његовог превазилажења}

Да су места неодређености (Ингарден), неизговорене информащије (Perelman and Olbrechts-Tyteca 1969: 8), празна места (Изер), пукотине (rupture, Рабинович 1987), како год терминолошки одредили разне видове ускраћивања информација и перспектива у књижевном делу, саставни део његове структуре, запажање је које у домену теорије књижевности можемо пратити од Ингардена, преко критике читалачког одговора, до когнитивних наративних теорија, а у читалачкој пракси готово увек, независно од књижевноисторијског периода коме припада дело које читамо. ${ }^{25}$ Оно што је важније од констатације њиховог постојања у структури књижевног дела ${ }^{26}$,

\footnotetext{
${ }^{25}$ Иако постоје поједине студије (IZER 1978: 100-100) које устврђују смањење празних места у делима реализма, а пораст у модернистичким и постмодернистичким делима, општи је став писаца, теоретичара и читалаца да свет књижевног дела, односно да његови поједини елементи никада не могу бити свестрано приказани.

${ }^{26}$ Концепт могућих светова, афирмисан унутар модалне логике али и савремених когнитивнолингвистичких истраживања, значајно је утицао на сагледавање природе фикционалног текста. Основна теза теоретичара књижевности усмерених ка теорији могућих светова тиче се непотпуности фикционалних светова, што је последица њиховог конструисања. Међутим, у овом контексту, непотпуност фикционалног света је његова универзална позитивна одлика јер доприноси његовој екстензивности и има важну улогу у процесу читања: „Varijabilna zasićenost fikcionalnih svetova predstavlja izazov za čitaoca; utoliko veći, ukoliko se zasićenost sveta smanjuje.” (DOLEŽEL 2008: 178) У односу на ову тезу чију традицију можемо пратити унутар других методолошких оријентација у проучавању књижевности (од феноменолошке, па до критике читалачког одговора), истраживање алтернативних, неактуелизованих (виртуелних) светова приче као последица непотпуности фикционалног текста и видова његове екстензивности, новијег је датума. У светској науци о књижевности екстензивност „света приче” предмет је анализе Лубомира Долежела и Мери-Лор Рајан, а у нашој науци о књижевности овај проблем дуги низ година истражује Снежана Милосављевић Милић. Поменута аторка
} 
јесте њихов ефекат у процесу читања који увек резултује читаочевом интеракцијом са текстом.

Када је у питању читаочева активност током попуњавања поменутих недоречености и ускраћивања, дијахронијским прегледом теорија читања уочавамо да су теоретичари оријентисани ка читаоцу били су усмерени ка различитим аспектима овог процеса: у тежишту феноменолошке теорије читања Романа Ингардена била је структура књижевноуметничког текста; Волфганг Изер је међу првим теоретичарима дао типолошки преглед празних места, указао на интерактивни процес њиховог попуњавања импликацијама из текста, а начин тражења спона назвао је „модусом лутајућег мотришта” унутар којег је указао на конкретне читаочеве активности, од сажимања до интерференције оквира у процесу читања. Изер је уједно први теоретичар читања који је указао на динамичку активност конфигурисања значења књижевног текста. Паралелно са Изером који при опису процеса читања полази од енкодиране стратегије текста, те у његовој структури налази узроке потоњих ефеката у поменутом процесу и у конфигурисању значења, поједини теоретичари читалачког одговора (Стенли Фиш, Норман Холанд) усмеравају се ка опису реакција стварних (емпиријских, извантекстовних) читалаца у процесу попуњавања празних места, односно током читања књижевног текста. Потом, једна струја теоретичара читања (Харолд Блум, Хејден Вајт, Стивен Гринблат, Елен Сполски и др.) усмерава се ка анализи утицаја контекста (историјског, идеолошког, родног) на интерпретацију књижевног текста.

У контексту теорије могућих светова (DOLEŽEL 2008: 177-181), празнине у текстури наратива сматрају се нужним и универзалним својством фикционалних светова, а као њихова примарна функција издваја се екстензивност, што природно проистиче из концепта света приче такође афирмисаног унутар поменуте теорије, а методолошки даље развијаног у посткласичној, когнитивној наратологији. Окренути ка читаоцу, когнитивни наратолози највећи изазов процесу читања налазе управо у варијабили засићености (односно, интензивирању непотпуности) фикционалних светова. На Изеровом трагу, когнитивни теоретичари читања процес читања одређују као интеракцију између текста и читаоца, при чему одлуке емпиријских читалаца у вези са превазилажењем непотпуности текста резултују различитим реализацијама ${ }^{27}$. Когнитивни теоретичари читања заинтересовани су и за естетску функцију празнина,

je, указујући на поређења и симулиране наративе као видове виртуелних наратива и осветлевши њихову улогу у процесу читања, дала значајан допринос посткласичним наратолошким истраживањима и савременим теоријама читања.

${ }^{27}$ По Изеру, највећи степен читаочеве слободе у конфигурисању значења наратива налази се у самосталности и субјективности његових одлука (закључивања). 
односно имплицитности у тексту. Међутим, први корак у вези са превазилажењем празнина и даље су импликације, односно контекстуални, реторички, конотативни или други видови имплицитности који се даље могу разложити на позитивне (различите маркере наговештаја присуства недостајаће информације у виду алузија, инсинуација и др. текстуалних, односно „ко-текстуалних” сигнала) и негативне (лакуне). Лубомир Долежел празнине у текстури наратива класификује према њиховом опсегу и функцијама које врше. ${ }^{28}$

На појединим Изеровим (1978: 140) запажањима у вези са функцијама емпиријског читаоца, попут оног да читаочево искуство неизбежно „боји” свет књижевног дела јер га, приликом формирања менталних слика (на основу информација из текста), неминовно надграђују залихе личног искуства читаоца, изграђено је више концепата посткласичних когнитивних наратолошких истраживања, почев од оквира (frame), преко разних видова натурализација наратива, ауторске публике и др. Од последње деценије 20. века, когнитивно усмерени теоретичари читања истражују утицај когнитивних оквира и скрипти (схема) током процеса читања, односно, интеракцију између читаочевих когнитивних способности, усвојених лингвистичких, социјалних и културних информација и књижевног текста који је предмет рецепције. Стога можемо закључити да најзначајнији допринос имплицитног читаоца савременим теоријама читања лежи управо у сусрету текста и емпиријског читаоца унутар једног концепта, односно у амбигвитетном ${ }^{29}$ карактеру имплицитног читаоца (као текстуалне стратегије и интерпретативног метода, односно као улоге коју узима емпиријски читалац). Готово сви поменути посткласични концепти који се односе на читаочев удео у процесу конфигурисања значења текста имају амбигвитетни карактер.

Концепт имплицитног читаоца заступљен је и у посткласичној реторичкој теорији наратива Џејмса Фелана; међутим, Фелан поменути Изеров концепт користи као синоном свом концепту ауторске (идеалне) публике. ${ }^{30}$ Реторички и наративно-етички усмерене студије Џејмса Фела-

\footnotetext{
${ }^{28}$ На сличан начин, Мери-Лор Рајан (1980: 303-422) наративе класификује на основу степена њихове непотпуности, односно степена „пражњења” идеалног модела потпуног света (стварног света). Тако највиши степен потпуности, како сматра поменута ауторка, поседује реалистичка фикција.

${ }^{29}$ Слично истиче и аутор одреднице „Implied Reader” у Routledge Encyclopedia of Narrative Theory (NINING 2008: 240).

${ }^{30}$ Концепт ауторске публике Џејмса Фелана односи се на хипотетичку идеалну публику за коју аутор конструише текст и која ће га у потпуности разумети, односно која ће открити и функцију имплицитног аутора (у Фелановој теорији, спољашњу и унутрашњу форму избор и распоред елемената) и уграђену стратегију читања, а, самим тим и значења датог наративног текста.
} 
на осветлеле су на вишеструке могућности примене Изеровог концепта у тумачењу широког корпуса прозног (али и стиховног) стваралаштва. Имплицитни читалац, односно уграђена, интендирана стратегија читања и (идеална) ауторска публика у Фелановој теорији се анализирају преко кључних проблема унутар интеракције текста и читаоца: наративне прогресије и читалачких судова који директно усмеравају даље читање, стратегија и функција поуздане/непоуздане нарације у процесу читања, односа између нестабилности у тексту и тензија у дискурсу у процесу рецепције, и др. ${ }^{31}$

Посткласичне наратолошке концепције попут теорије урањања и теорије ума развиле су потенцијал Изеровог лутајућег мотришта и трагања за импликацијама зарад превазилажења места неодређености, те разне видове конкретизација. На читаочевом откривању мреже поступака помоћу којих ће приповедано моћи да повеже са са познатим моделима перцепције стварности и тако га натурализовати ${ }^{32}$, утемељено је више концепата посткласичне наратологије међу којима су најутицајнији оквири и скрипти, наративизација, утеловљење (искуственост) и нормализација.

\section{Цитирана литература}

BOJANIĆ ĆIRKOVIĆ 2018: BOJANIĆ ĆIRKOVIĆ, Mirjana. „Savremene teorije čitanja”. Philologia Mediana X, br. 10, Niš: Filozofski fakultet, 2018, str. 89-102. [orig.] БОЈАНИЋ ЋИРКОВИЋ, Мирјана. „Савремене теорије читања". Philologia Mediana X, бр. 10, Ниш: Филозофски ф факул те т, 2018, стр. 89-102.

WOLF 2006: WOLF, Werner. „Framing Borders in Frame Stories”. U: Framing Borders in Literature and Other Media. Eds: W. Wolf and Walter Bernhart, Studies in Intermediality, 1. Amsterdam: Rodopi 2006, 1-40.

DOLEŽEL 2008: DOLEŽEL, Lubomir. Heterokosmika: fikcija i mogući svetovi. Beograd: Službeni glasnik 2008.

IZER 1974: IZER, Wolfgang. The Implied Reader: Patterns of Communication in Prose Fiction from Bunyann to Beckett. Baltimore and London: The John Hopkins University Press, 1974.

IZER 1978: IZER, Wolfgang. The Act of Reading: A Theory of Aesthetic Response. London and Henley: Routledge \& Kegan Paul, 1978.

\footnotetext{
${ }^{31}$ Док читалачки судови у вези са наративом и непоуздана нарација представљају даљу разраду теоријских поставки Вејна Бута, остали проблеми о којима расправља Џејмс Фелан извориште имају у Изеровој теорији читања.

${ }^{32}$ Натурализација је концепт Џонатана Калера афирмисан у Структуралистичкој поетищи (1975). Односи се на мрежу поступака којима реципијент наративни текст повезује са одређеним моделима стварности, културом, или пак са жанровским конвенцијама.
} 
IZER 1989: IZER, Wolfgang. „Interakcija između teksta i čitaoca”. Književna kritika, XX, 3, 1989, 51-60.

IZER 1992: IZER, Wolfgang. „Lutajuće motrište i čitateljska svijest”. Biti, Vladimir (prir.), Suvremena teorija pripovedanja. Zagre: Globus 1992, 158-177.

IZER 2002: Izer, Wolfgang. „Proces čitanja: jedan fenomenološki pristup”. U: Lešić, Zdenko (ur.). Poststrukturalistička čitanka: nova čitanja. Sarajevo: Kaligraf, 2002.

INGARDEN 1971: INGARDEN, Roman. O saznavanju književnog umetničkog dela. Beograd: SKZ, 1971.

MILOSAVLjEVIĆ MILIĆ 2006: MILOSAVLJEVIĆ MILIĆ, Snežana, Modeli komentara u srpskom romanu 19. veka. Niš: Prosveta. [orig.] Милосављевић Милић, Снежана, Модели коментара у српском роману 19. века. Ниш: Просвета, 2006.

MILOSAVLjEVIĆ MILIĆ 2015: MILOSAVLJEVIĆ MILIĆ, Snežana. „Negativni svetovi priče”, Književna istorija, XLVII, br. 155, Beograd: Institut za književnost i umetnost, 2015, str. 57-82. [orig.] МИЛОСАВЉЕВИЋ МИЛИЋ, Снежана. „Негативни светови приче”, Кюижевна историја, XLVII, бр. 155, Београд: Институт за књижевност и уметност, 2015, стр. $57-82$.

MILOSAVLJEVIĆ MILIĆ 2016: MILOSAVLJEVIĆ MILIĆ, Snežana. Virtuelni narativ: ogledi iz kognitivne naratologije. Novi Sad - Sremski Karlovci: Izdavačka knjižarnica Zorana Stojanovića, 2016.

TOMPKINS 1980: JANE, Tompkins (editor). Reader-Response Criticism: From Formalism To Post-Structuralism. Baltimore and London: The John Hopkins University Press 1980.

NINING 2008: NÜNNING, Ansgar. „Implier Reader”. In: D. Herman et al. (eds.). Routledge Encyclopedia of Narrative Theory. Routledge: London and New York 2008, 240.

POPOV 1993: POPOV, Jovan. Oslobođeni čitalac. Novi Sad: Matica srpska 1993. [orig.] Попов, Јован. Ослобођени читалач. Нови Сад: Матица српска 1993.

RAIČEVIĆ 1997: RAIČEVIĆ, Gorana. Čitanje kao kreacija. Novi Sad: Savez pedagoških društava Vojvodine 1997. [orig.] Раичевић, Горана. Читање као креација. Нови Сад: Савез педагошких друштава Војводине 1997.

FELAN 2011: PHELAN, James. „Rhetoric, Ethics and Narrative Communication: Or, from Story and Discourse to Authors, Resources and Audiences". Soundings: An Interdisciplinary Journal, Vol. 94, No.1/2 (Spring/Summer). USA: Penn State UP 2011, 55-75.

FIŠ 1981: FISH, Stanley. „Why No One’s Afraid Of Wolfgang Iser”. Diacritics, Vol. 11, No. 1 (Spring, 1981), John Hopkins University Press 1981, 2-13. 
Мирьяана Боянич Чиркович

\section{КОНЦЕПТ ИМПЛИЦИТНОГО ЧИТАТЕЛЯ ВОЛФГАНГ ИЗЕРА}

В работе систематизируют и критически рассматривают теоретическо-морфологические исследования имплицитного читателя, концепт афирмисанный Волфгангом Изером, являющийся значительным тэоретиком чтения в современной науке о литературе. Концепт имплицитного читателя соображается и в отношении с подходящими методологическими концептами наратологов и теоретиков чтения (наративной и авторской публикой Джеймс Фэлана) при чем в рекурсивном отношении осветливаются и новые перспективы концепта который является предметом обсуждения этой роботы. Значительная часть работы посвещен активностям, возможным ограничиванием эмпирического читателя в роли имплицитного читателя. В выводе роботы указываем на вклад концепта имплицитного читателя современным теориям чтения и на причины его актуальности в науке о литературе.

Ключевые слова: Вольфганг Изер (Wolfgang Iser), имплицитный читател, разрыв, значение, теории чтения 